\title{
Diversity among Greengram Germplasm to Powdery Mildew Resistance Caused by Erysiphe polygoni DC
}

\author{
S.K. Pooja ${ }^{1}$ and Sumangala Bhat $^{2 *}$ \\ ${ }^{1}$ Department of Biotechnology, College of Agriculture, University of Agricultural Sciences, \\ Dharwad-580005, Karnataka, India \\ ${ }^{2}$ Department of Genetics and Plant breeding, College of Agriculture, Hanumanmatti, India \\ *Corresponding author
}

\begin{tabular}{|l|}
\hline Ke y w or d s \\
Powdery mildew, \\
$\begin{array}{l}\text { Erysiphe polygoni, } \\
\text { Genotype, Resistant }\end{array}$ \\
\hline Article Info \\
\hline $\begin{array}{l}\text { Accepted: } \\
\text { 20 June } 2019 \\
\text { Available Online: } \\
\text { 10 July } 2019\end{array}$ \\
\hline
\end{tabular}

A B S T R A C T

Greengram also known as mungbean is an important pulse crop with remarkable source of high quality protein, vitamins, fibres and amino acid profiles. In India, it stands third in production. The lower productivity of greengram is attributed to biotic stresses, among which powdery mildew caused by Erysiphe polygni is one of the major fungal diseases and in severe cases it covers entire leaf area, affects the photosynthetic activity, reduces mungbean yield more than $50 \%$. In the present study, 130 genotypes were screened against E. polygoni under natural epiphytotic condition at Main Agricultural Research Station, Dharwad during kharif and rabi, 2016. Among these, during kharif 2016 four genotypes (GPM-19, NUL-7, Vigna umbellata and Vigna trilobata) showed immune response, three genotypes (COGG-913, VAIBHAV and TARM1) were moderately resistant, six genotypes (GPM-10, GPM-23IPU-94-1, IPU-2-4, TBM-96-2 and IC277014)) showed susceptible reaction, 119 genotypes were highly susceptible to the disease. During rabi 2016, three genotypes viz., GPM-19, V. umbellata and V. trilobata showed immune response and four genotypes viz., NUL-7, COGG-913, TARM1 and Vaibhav showed moderately resistant response. Nine genotypes viz., IPU-94-1, IPU-2-43, TCR-262 V. sylvestris, GPM-23, GPM-10, TBM-96-2, IV277014 V. sylvestris, TCR-218 V. sublobata and IC-251416 V. sublobata showed susceptible reaction and the remaining 114 genotypes were rated as highly susceptible to the disease. None of the genotypes showed resistant response. These identified immune genotypes can be used in the development of resistant cultivars.

\section{Introduction}

Greengram is an important pulse crop with remarkable source of high quality protein, vitamins, fibers and amino acid profiles. In India, it stands third in production, occupying nearly 33.375 lakh hectare area with 15.383 lakh tones production with the productivity of $461 \mathrm{~kg} / \mathrm{hectare}$ (Tiwari and Shivhare, 2016). The lower productivity in mungbean is attributed to biotic stress, among which powdery mildew caused by Erysiphe polygni is the major fungal disease of mungbean. It is a kharif season disease particularly when 
there is a low temperature $\left(20-25^{\circ} \mathrm{C}\right)$ and high air current which helps in the movement of the spore and high humidity (80-90 \%) (Patil et al., 1989). The fungus produces initially faint slightly dark areas on leaves. These areas develop into small white powdery patches. They enlarge and coalesce to form a complete coating of white powder on upper surface of the leaves, stem and pods. In case of severe infection, it spreads to all over the leaves and cause defoliation. The disease induces forced maturity in plants causing heavy yield losses. The disease usually covers host leaf surface area there by affecting the photosynthetic activity and physiological changes leads to the potential reduction in the yield. The yield reduction by this disease ranges from $20-40 \%$ in the absence of prevention (Fernandez and Shanmugasundaram, 1988) and 100 per cent when it occurs at the seedling stage (Reddy et al., 1994). Cultivation of resistant genotypes is an effective and reliable method to combat disease. Identification of resistant sources is the prerequisite in the development of resistant varieties. Therefore, in this study an attempt was made to identify resistant genotypes against powdery mildew.

\section{Materials and Methods}

\section{Experimental location and weather condition}

The field experiment was conducted at Main Agricultural Research Station (MARS), College of Agriculture, Dharwad. Geographically, Dharwad is located at $15^{\circ} 31^{\prime}$ North latitude and $75^{\circ} 07^{\prime}$ East longitudes at an altitude of $678 \mathrm{~m}$ above mean sea level with an average rainfall of about $720 \mathrm{~mm}$.

\section{Phenotypic screening of mungbean accessions for powdery mildew resistance}

One hundred and thirty mungbean accessions (Table 1) were obtained from AICRP on
MULLaRP UAS, Dharwad and Indian Institute of Pulse Research (IIPR), Kanpur. Seeds of these accessions were sown in augmented design in MARS, Dharwad field, during kharif and rabi, 2016.

In order to assess the disease incidence, double row of spreader variety viz., DGGV2 (highly susceptible to powdery mildew) was sown after every five rows of test entries and also around the border of the experimental plot. Common agronomical practices recommended to mungbean were adopted to grow healthy crop without adopting any plant protection measures. The genotypes were screened for powdery mildew disease in kharif and rabi, 2016 under natural epiphytotic conditions.

Genotypes were grouped into different classes based on two parameters viz.

Disease reaction

Percent disease index (PDI)

For disease reaction, percentage of leaf area covered by the disease powdery patches was scored manually. From each genotype five plants were randomly selected and from each plants three leaves i.e., upper leaves, middle leaves and lower leaves were taken for calculation of percentage of leaf covered by the disease spores. The percentages was then translated into a disease rating of 0 to 9 following Mayee and Datar (1986) (Table 2) (Fig. 1), and then average was taken for the calculation of PDI using the formula (Wheeler, 1969), given below.

\section{Percentage disease index were calculated using the formula}

$\mathrm{PDI}=$

Sum of individual ratings

Number of leaves observed $\times$ maximum scale 


\section{Results and Discussion}

\section{Screening of mungbean accessions for powdery mildew resistance}

The per cent disease index (PDI) among 130 genotypes ranged from 0 to $98.3 \%$, during kharif, 2016. Among the accessions screened, four genotypes (NUL- 7, GPM- 19, $V$. umbellata and $V$. trilobata) showed immune response, three genotypes viz., COGG- 913, VAIBHAV and TARM1 showed moderately resistant response respectively. Six genotypes such as GPM- 10, GPM-23, IPU-94- 1, IPU2- 43, TBM-96-2 and IC277014 V. sylvestris were rated as susceptible and the remaining 119 genotypes were rated as highly susceptible to the disease (Table 3).

During rabi, 2016, the PDI ranged from 0 to $93.10 \%$. Three genotypes viz., GPM-19, $V$. umbellata and $V$. trilobata showed immune response, four genotypes viz., (NUL-7, COGG-913, TARM1 and Vaibhav) showed moderately resistant response respectively.

Nine genotypes viz., IPU-94-1, IPU-2-43, TCR-262 V. sylvestris, GPM-23, GPM-10, TBM-96-2, IV277014 V. sylvestris, TCR-218 $V$. sublobata and IC-251416 V. sublobata showed susceptible reaction to the disease and the remaining 114 genotypes were rated as highly susceptible to the disease (Table 3 ).

Previously Kumar (2015) and Sarkale (2015) also observed immune response to powdery mildew by two wild relatives $V$. umbellata and $V$. trilobata and moderately resistant response by TARM1.

However, Khare et al., (1998) reported resistant reaction of TARM1 to the powdery mildew disease. Also Mandhare et al., (2008) evaluated eighty two genotypes against powdery mildew and yellow mosaic virus under natural epiphytotic condition. Of the eighty two genotypes screened, Vaibhav, BPMR-145, TARM18, Phule-M-2003-3, Phule-M-2002-13, Phule-M-2002-17, PhuleM-2001-3 and Phule-M-2001-5 were resistant to powdery mildew and moderately resistant to yellow mosaic virus.

Nair et al., (2015) evaluated seventy diverse greengram genotypes in field under natural epiphytotic condition during kharif, 2010 and rabi, 2009-2010.

In rabi only two genotypes (TARM1 and Pragya) showed highly resistant response to the powdery mildew disease.

TARM1, a variety of mungbean grown in Chattisgarh and Raipur region and Vaibhav grown in Rahuri which were resistant to powdery mildew were found to be moderately resistant in the present study.

Genotypes do not perform same across seasons and environments because response of the genotypes to the disease under field conditions influenced by various factors such as pathogen race, congenial environmental conditions etc.

In conclusion, of the one hundred and thirty genotypes screened during kharif and rabi, 2016, three genotypes viz., GPM-19, $V$. umbellata, $V$. trilobata (Fig. 2) showed immune response to the disease in both the seasons and genotypes COGG-913, TARM1 and Vaibhav showed moderately resistant response during kharif, 2016.

During rabi COGG-913, TARM1, Vaibhav and NUL-7 were found to be moderately resistant. None of the genotypes showed resistant and moderately susceptible response to the disease in both the season. 
Table.1 List of mungbean accessions screened for powdery mildew incidence

\begin{tabular}{|c|c|c|c|c|c|}
\hline Sl. No. & Varieties & $\begin{array}{l}\text { Sl. } \\
\text { No. }\end{array}$ & Varieties & $\begin{array}{l}\text { Sl. } \\
\text { No. }\end{array}$ & Varieties \\
\hline $\mathbf{1}$ & China mung & 45 & GPM-10 & 89 & ML- 1256 \\
\hline 2 & NL- 3 & 46 & 2.Mutant-29-3 & 90 & ML- 729 \\
\hline 3 & GG- 38 & 47 & 11.Mutant-60-10 & 91 & ML- 935 \\
\hline 4 & GPM- 21 & 48 & GPM- 25 & 92 & ML- 1059 \\
\hline 5 & GG- 22 & 49 & 9.Mutant-60-8 & 93 & ML- 682 \\
\hline 6 & SEL- 4 & 50 & DGGV2 & 94 & IPM05- 3- 21 \\
\hline 7 & GG- 62 & 51 & GPM- 3 & 95 & IPM- 03-2 \\
\hline 8 & GG- 42 & 52 & GPM- 4 & 96 & IPM- 306-6 \\
\hline 9 & GPM- 18 & 53 & 12.Mutant-60-11 & 97 & IPM9901- 10 \\
\hline 10 & NL- 10 & 54 & 13.Mutant-60-12 & 98 & IPM03- 1 \\
\hline 11 & GG- 46 & 55 & GG- 54 & 99 & IPM-02- 23 \\
\hline 12 & GPM- 11 & 56 & GPM- 12 & 100 & IPM- 5-3-22 \\
\hline 13 & 15.Mutant70-3 & 57 & GPM- 20 & 101 & IPM-99-3 \\
\hline 14 & GPM- 9 & 58 & GPM- 28 & 102 & IPM- 02-1 \\
\hline 15 & 5.Mutant 29-6 & 59 & GPM- 14 & 103 & MH-3-18 \\
\hline 16 & TAP-7 & 60 & 10.Mutant-60-9 & 104 & PUSA 672 \\
\hline 17 & GPM- 29 & 61 & GPM- 24 & 105 & DMG-1045 \\
\hline 18 & GPM- 23 & 62 & GPM-13 & 106 & BDYR- 1 \\
\hline 19 & NL- 8 & 63 & COGG- 913 & 107 & TMB-96-2 \\
\hline 20 & GPM- 17 & 64 & IPM-31266K- 1 & 108 & HUM- 1 \\
\hline 21 & GPM- 30 & 65 & PANTMUNG & 109 & PM-3 \\
\hline 22 & Mutant- 29-4 & 66 & IPM- 409- 4 & 110 & AKM99-4 \\
\hline 23 & 14.Mutant60-18 & 67 & IPM- 205- 7 & 111 & HUM-7 \\
\hline 24 & GPM- 74 & 68 & NM- 1 & 112 & GM- 4 \\
\hline 25 & 1.Mutant 29-1 & 69 & IPM- 430- 4 & 113 & SML- 668 \\
\hline 26 & 7.Mutant-60-4 & 70 & IPM- 544-8 & 114 & SM- 47 \\
\hline 27 & GPM- 19 & 71 & IPM-312-134-135K & 115 & PUSA9531 \\
\hline 28 & GPM- 27 & 72 & Vaibhav & 116 & UPM98-1 \\
\hline 29 & DLGG- 7 & 73 & TARM1 & 117 & PM-2 \\
\hline 30 & DLGG- 11 & 74 & Ganga & 118 & BM- 63 \\
\hline 31 & NL- 2 & 75 & PM- 5 & 119 & BM- 64 \\
\hline 32 & GPM- 6 & 76 & JBT/ 46/ 23 & 120 & DMG-1030 \\
\hline 33 & 8.Mutant-60-5 & 77 & EC520011 & 121 & UPM02-18 \\
\hline 34 & GG- 86 & 78 & PDM- 191 & 122 & IPU94-1 \\
\hline 35 & 6.Mutant-29-10 & 79 & PDM- 681 & 123 & IPU2-43 \\
\hline 36 & GPM- 22 & 80 & PDM- 87 & 124 & NUL-7 \\
\hline 37 & PDM-99-28 & 81 & PDM- 262 & 125 & TCR-218 V. sublobata \\
\hline 38 & GG- 79 & 82 & PDM- 11 & 126 & Ic277014 V. sylvestris \\
\hline 39 & GPM-7 & 83 & IPM- 5- 3- 6 & 127 & TCR-262 V. sylvestris \\
\hline 40 & ML- 881 & 84 & ML- 512 & 128 & IC-251416 V. sublobata \\
\hline 41 & GG- 36 & 85 & IPM- 2- 17 & 129 & Vigna umbellata \\
\hline 42 & 3.Mutant-29-3 & 86 & IPM2K14- 9 & 130 & Vigna trilobata \\
\hline 43 & GG- 23 & 87 & ML-1257 & & \\
\hline 44 & GPM-16 & 88 & ML- 515 & & \\
\hline
\end{tabular}


Table.2 Disease rating scale used for scoring ( Mayee and Datar, 1986)

\begin{tabular}{|c|l|l|}
\hline Numerical rating & \multicolumn{1}{|c|}{ \% of leaf area covered } & \multicolumn{1}{|c|}{ Disease reaction } \\
\hline $\mathbf{0}$ & $\begin{array}{l}\text { No symptoms on leaf } \\
\text { Small scattered powdery speaks covering 1\% or } \\
\text { less area of leaf }\end{array}$ & Resistant \\
\hline $\mathbf{3}$ & $\begin{array}{l}\text { Small, scattered powdery lesions covering 1-10\% } \\
\text { of the leaf area }\end{array}$ & Moderately resistant \\
\hline $\mathbf{5}$ & $\begin{array}{l}\text { Powdery lesions enlarging with grey coloured } \\
\text { powdery mass covering 11-25\% of leaf area }\end{array}$ & Moderately susceptible \\
\hline $\mathbf{7}$ & $\begin{array}{l}\text { Grey coloured powdery growth covering 26-50 \% } \\
\text { of the leaf area }\end{array}$ & Susceptible \\
\hline $\mathbf{9}$ & $\begin{array}{l}\text { Gray coloured patches of powdery growth covering } \\
\text { 51\% Or more of leaf area on leaves, leaf become } \\
\text { dry }\end{array}$ & Highly susceptible \\
\hline
\end{tabular}

Table.3 Grouping of mungbean accessions based on response to powdery mildew Disease according to Mayee and Datar (1986)

\begin{tabular}{|c|c|c|}
\hline & Kharif, 2016 & Rabi, 2016 \\
\hline $\begin{array}{l}\text { Disease rating and } \\
\text { Percent leaf area } \\
\text { infected }\end{array}$ & & enotypes \\
\hline $\begin{array}{l}\text { Immune } \\
0(0.00 \%)\end{array}$ & $\begin{array}{l}\text { GPM-19 \& NUL-7, Vigna umbellate and Vigna } \\
\text { trilobata }\end{array}$ & GPM-19, Vigna umbellate and Vigna trilobata \\
\hline $\begin{array}{l}\text { Resistant } \\
1(<1 \%)\end{array}$ & - & - \\
\hline $\begin{array}{l}\text { Moderately } \\
\text { resistant } \\
3(1-10 \%)\end{array}$ & COGG-913,TARM1 and VAIBHAV & COGG- 913, TARM1, VAIBHAV and NUL-7 \\
\hline $\begin{array}{l}\text { Moderately } \\
\text { susceptible } \\
5(11-25 \%)\end{array}$ & - & - \\
\hline $\begin{array}{l}\text { Susceptible } \\
7(26-50 \%)\end{array}$ & $\begin{array}{l}\text { GPM-23, GPM-10, TMB-96-2, IPU-94-1, and } \\
\text { IPU-2-43 IC277014 V. sylvestris }\end{array}$ & $\begin{array}{l}\text { GPM- 23, GPM-10, TMB-96-2, IPU94-1, IPU2-43, } \\
\text { TCR-218 V. sublobata, IC277014 V. sylvestris, TCR-262 } \\
\text { V. sylvestris and IC-251416 V. sublobata }\end{array}$ \\
\hline $\begin{array}{l}\text { Highly susceptible } \\
\quad 9(>51 \%)\end{array}$ & $\begin{array}{l}\text { China mung, NL-3, GG-38, GPM-21, GG-22, } \\
\text { SEL-4, GG-62, GG-42, GPM-18, NL- 10, GG-46, } \\
\text { GPM-11, 15. Mutant-70-3, GPM-9, 5. Mutant-29- } \\
\text { 6, TAP-7, GPM-29, GPM-23, NL-8, GPM-17, } \\
\text { GPM-30, Mutant-29-4, 14. Mutant-60-18, GPM- } \\
\text { 74, 1. Mutant-29-1, 7.Mutant-60-4, GPM-27, } \\
\text { DLGG-7, DLGG-11, NL-2, GPM-6, 8. Mutant-60- } \\
\text { 5, GG-86, 6. Mutant-29-10, GPM-22, PDM-99-28, } \\
\text { GG-79, GPM-7, ML-881, GG-36, 3. Mutant-29-3, } \\
\text { GG-23, GPM-16, 2. Mutant-29-3, 11. Mutant-60- } \\
\text { 10, GPM-25, 9. Mutant-60-8, DGGV2, GPM-3, } \\
\text { GPM-4, 12. Mutant-60-11, 13. Mutant-60-12, GG- } \\
\text { 54, GPM-12, GPM-20, GPM-28, GPM-14, 10. } \\
\text { Mutant-60-9, GPM-24, GPM-13, PANTMUNG-2, } \\
\text { IPM-409-4, IPM-205-7, IPM-99-125, NM-1 IPM- } \\
\text { 430-4, IPM-544-8, Ganga-8, PM-5, JBT/46/23, } \\
\text { EC520011, PDM-191, PDM-681, PD-87, PDM- }\end{array}$ & $\begin{array}{l}\text { China mung, NL- 3, GG- 38, GPM- 21, GG- 22, SEL- 4, } \\
\text { GG- 62, GG-42, GPM- 18, NL- 10, GG- 46, GPM- 11, } \\
\text { 15.Mutant70-3, GPM- 9, 5.Mutant 29-6, TAP-7, GPM- } \\
\text { 29, NL- 8, GPM- 17, GPM- 30, Mutant- 29-4, } \\
\text { 14.Mutant60-18, GPM- 74, 1.Mutant 29-1, 7.Mutant-60- } \\
\text { 4, GPM- 27, DLGG- 7, DLGG- 11, NL- 2, GPM- 6,, } \\
\text { 3.Mutant-60-5, GG- 86, 6.Mutant, 29-10, GPM- 22, } \\
\text { PDM-99-28, GG- 79, GPM-7, ML- 881, GG- 36, } \\
\text { 3.Mutant-29-3, GG-23, GPM-16, 2. Mutant-29-3, } \\
\text { 11.Mutant-60-10, GPM- 25, 9. Mutant-60-8, DGGV2, } \\
\text { GPM- 3, GPM- 4, 12. Mutant-60-11, 13.Mutant-60-12, } \\
\text { GG- 54, GPM- 12, GPM- 20, GPM- 28, GPM- 14, } \\
\text { 10.Mutant-60-9, GPM- 24, GPM-13, IPM-31266K- 1, } \\
\text { PANTMUNG, IPM- 409- 4, IPM- 205- 7, NM- 1, IPM- } \\
\text { 430- 4, IPM- 544-8, IPM-312-134-135K, Ganga, PM- 5, } \\
\text { JBT/ 46/ 23, EC520011, PDM- 191, PDM- 681, PDM- } \\
\text { 87, PDM- 262, PDM- 11, IPM- 5- 3- 6, ML- 512, IPM- }\end{array}$ \\
\hline
\end{tabular}




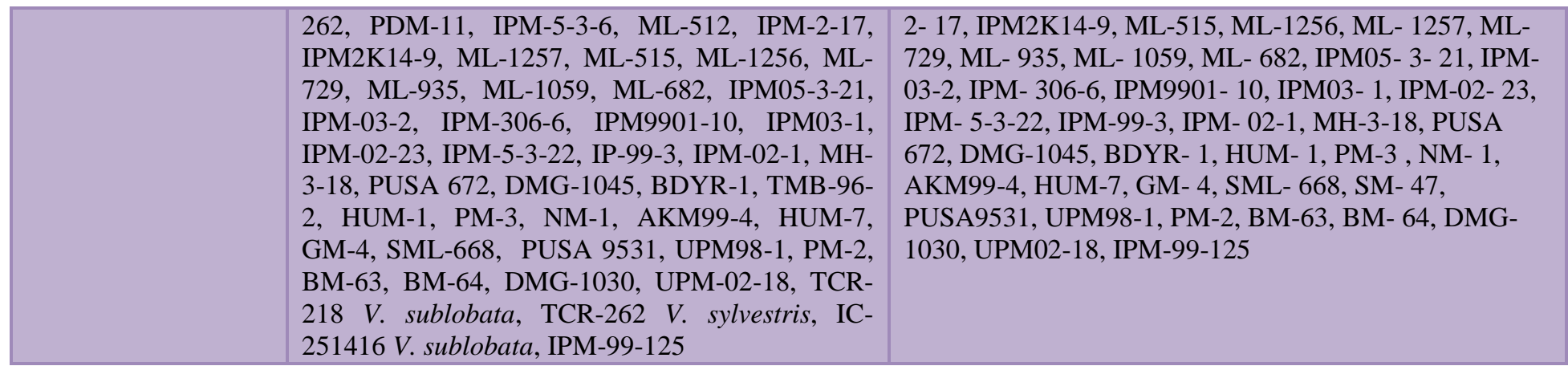

Fig.1 Disease rating scale used for powdery mildew

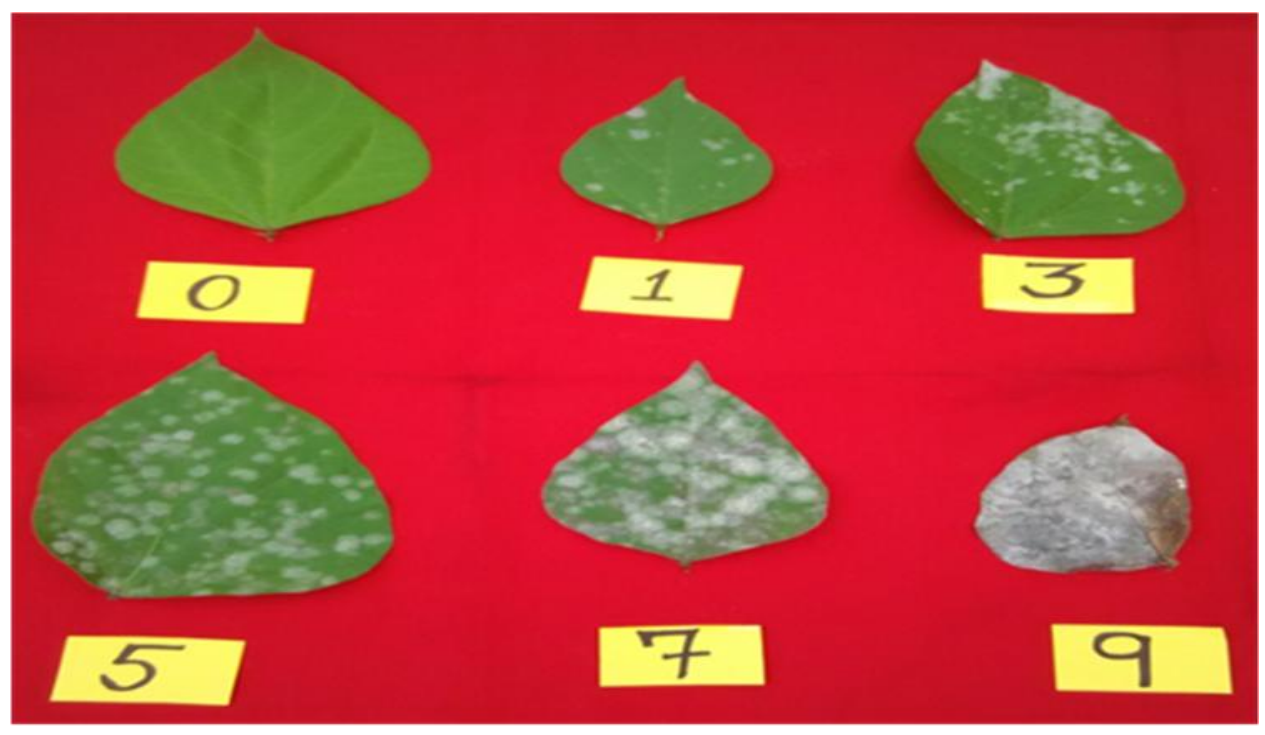

Fig.2 From top left DGGV2, Vigna umbellate, Vigna trilobata and GPM-19
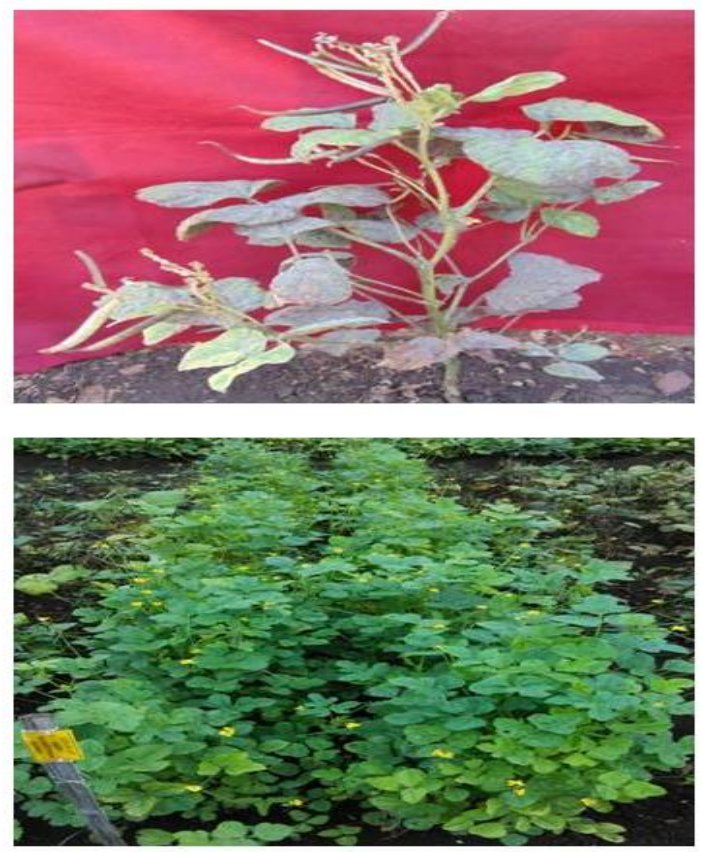
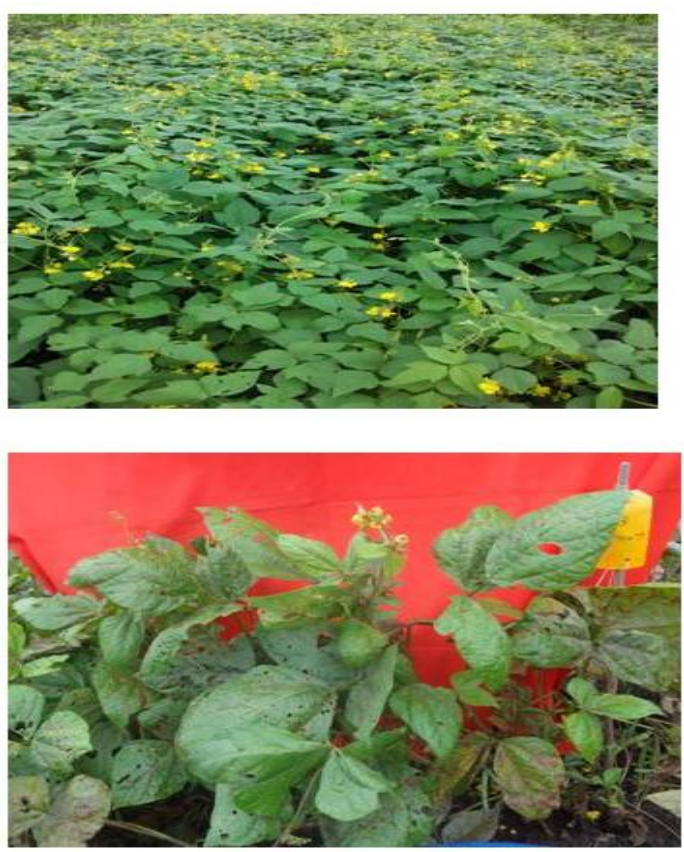
The identified immune genotypes in the present study can be utilized in the breeding programme for the development of powdery mildew resistant. Therefore these genotypes could be used further in development of mungbean variety resistant to powdery mildew.

\section{Acknowledgements}

We thank AICRP on MULLaRP, Main Agricultural Research Station, University of Agricultural Sciences, Dharwad for sparing the materials and field assistance and IIPR, Kanpur for sparing the materials. Also we thank University of Agricultural Sciences Dharwad for financial assistance to Pooja $S$. $\mathrm{K}$ in the form of fellowship.

\section{References}

Fernandez, G. C. J. and Shanmugasundaram, S., 1988, The AVRDC mungbean improvement programme: The past, present and future. In: Proc. Second Int. Symp. Asian Vegetable Research and Development Center, Shanhua, Taiwan, pp. 58-70.

Khare, N., Lankpale, N. and Agarwal, K. C., 1998, Epidemiology of powdery mildew of mungbean in Chattisgarh region of Madhya Pradesh. J. Mycol. Plant Path., 28: 5-10.

Kumar, M., 2015, Molecular diversity studies in green gram genotypes differing for powdery mildew resistance. $M$. Sc. Thesis, Univ. Agric. Sci., Dharwad,
Karnataka (India).

Mandhare, V. K. and Suryawanshi, A. V., 2008, Dual resistance against powdery mildew and yellow mosaic virus. Agric. Sci. Digest, 28 (1): 39-41.

Mayee, C. D. and Datar, V. V., 1986, Phytopathometry Tech. Bull. No. 1-3. M. A. U., Parbhani (India), p. 146.

Nair, S. K., Nanda, H. C., Khare, N., Motiramani, N. K., Chandrakar, D. K. and Kotasthane, A. S., 2015, Resistance in mungbean genotypes against powdery mildew disease. J. Food Legumes, 28(2): 78-81.

Patil, N. K., Adiver, S. S., Hiremath, P. C., Anilkumar, T. P. and Hegde, R. K., 1989, Field reaction of greengram varieties to powdery mildew. Curr. Res., 18(6): 83.

Reddy, K. S., Pawar, S. E. and Bhatia, C. R., 1994, Inheritance of powdery mildew (Erysiphe polygoni D. C.) resistance in mungbean [Vigna radiata (L.) Wilczek]. Theor. Appl. Genet., 88: 945948.

Sarkale, A. P., 2015, Validation of molecular markers associated with powdery mildew resistance in mungbean. $M . S c$. Thesis, Univ. Agric. Sci., Dharwad, Karnataka (India).

Wheeler, B. E. J., 1969, An Introduction to Plant Diseases. John Wiley and Sons Ltd., London, p. 301.

Tiwari, A. K. and Shivhare, A, K., 2016, Pulses in India: Retrospect and prospects, Directorate of pulse development, Bhopal (M. P). 2: 81-96.

\section{How to cite this article:}

Pooja, S.K. and Sumangala Bhat. 2019. Diversity among Greengram Germplasm to Powdery Mildew Resistance Caused by Erysiphe polygoni DC. Int.J.Curr.Microbiol.App.Sci. 8(07): 2765-2771. doi: https://doi.org/10.20546/ijcmas.2019.807.345 